\title{
INVESTIGATIONS ON KAEMPHERIA GALANGA
}

LAKSHMI ARAMBEWELA*, ANUSHA PERERA, RENUKA THAMBUGALA R . L. C. WIJESUNDERA ${ }^{\mathrm{a}}$ and J. GUNATILEKE ${ }^{\mathrm{b}}$

Ceylon Institute of Scientific \& Industrial Research, 363, Bauddhaloka Mawatha, Colombo 7

a. Department of Botany, University of Colombo, Colombo 3

b. Coconut Research Institute, Lunuwila

(Reccived: 16 December 1999 ; accepted: 15 November 2000)

\begin{abstract}
The constituents of rhizome oil and root oil of Kaempheria galanga are similar in GLC studies. Ethyl cinnamate and ethyl p-methoxy cinnamate are the major constituents. The volatile oil content of the rhizome is higher than that of the root. The optimum time to harvest the rhizomes is at the age of one year hased on essential oil content. Higher yield is obtained in plants grown under coconut. The root and rhizome oils of Kuermpheria galarga showed marked activity against: Struphyllococcius aureus and Escherichia coli
\end{abstract}

Key words: Antimicrobial activity, GLC analysis, Kaempheria galanga, volatile oils

\section{INTRODUCTION}

Kaempheria galanga belongs to family Zingiberaceae and is distributed throughout the tropics and sub tropics of Asia and Africa. The rhizomes are traditionally used in medicine for the treatment of cough, pectoral infections $\mathrm{s}^{1,2}$, abdominal pain ${ }^{1}$, malaria ${ }^{1}$, heart dyspepsia, depression, fever, rheumatism, sore throat, sore eyes and wounds. Antimalarial, antispasmodic and antitumour activities too have been reported. ${ }^{1, *-4}$ The roots have shown antibacterial activities. The rhizomes are also used in perfumes and cosmetics. About 40 compounds including ethyl $p$ methoxycinnamate, and p-methoxy cinnamic acid have been reported in the volatile oil of $K$. galanga rhizomes found in other countries. ${ }^{2,5-6}$

The present studies deal with the composition of the volatile constituents, the antimicrobial activities of the rhizome and root oils of $K$. galanga as well as determining suitable conditions for cultivation and the optimum time for harvesting the plants.

\section{METHODS AND MATERIALS}

Plant material: Kaempheria galanga. L. ( Zingiberaceae) rhizomes and the roots were collected from plants grown in Colombo and Walpita and identified at the

\footnotetext{
* Corresponding author
} 
Botanical Gardens, Peradeniya. A voucher specimen is available in the herbarium in Peradeniya.

Determination of the chemical constituents of the plant: Samples of rhizomes and roots were collected from 1, 1 1/2 and 2 yr. old plants. The crushed rhizomes and roots were separately water distilled for $5 \mathrm{~h}$. using a Clevenger arm and the volatile oil was collected. The yields were estimated on a dry weight basis. The oil was analysed by Gas Liquid Chromatography using Shimadzu GC 8A equipped with a FI detector and a $10 \%$ Carbowax 20M column. Retention data, peak enhancement techniques and GC-MS data were used for identification of compounds

Table 1: Effect of maturity on the yield of volatile oils of $K$. galanga

\begin{tabular}{ccc}
\hline $\begin{array}{c}\text { Age of the Plant } \\
\text { (Year) }\end{array}$ & Rhizome & Root \\
\hline 1 & $7.28 \pm 0.43$ & $0.8 \pm 0.06$ \\
$11 / 2$ & $3.83 \pm 0.72$ & $1.32 \pm 0.5$ \\
2 & $4.4 \pm 0.28$ & $1.72 \pm 0.16$ \\
\hline
\end{tabular}

Table 2: Variation in major constituents of the essential oil of $K$. galanga rhizome with maturity

\begin{tabular}{lccc}
\hline Compound & \multicolumn{3}{c}{ Yield\% } \\
\cline { 2 - 4 } & 1 Year & 1 1/2 Years & 2 Years \\
\hline Camphene & 0.5 & 0.6 & 3.5 \\
1,8 cineol & 0.4 & 1.5 & 3.0 \\
Camphor & 10.7 & 3.1 & 3.8 \\
Borneol & 2.7 & 2.7 & 3.8 \\
Cinnamaldehyde & 0.23 & 0.8 & 0.7 \\
Ethyl Cinnamate & 25.3 & 35.0 & 40.0 \\
Quinazoline-4 & 0.2 & 0.2 & 0.03 \\
phenyl -3-oxide & & & 32.7 \\
Ethyl p-methoxy & 48.9 & 39.0 & \\
cinnamate & & & \\
\hline
\end{tabular}


Table 3: Variations in major constituents of the $K$. galanga root oil with maturity

\begin{tabular}{lccc}
\hline Compound & \multicolumn{3}{c}{ Yield\% } \\
\cline { 2 - 4 } & 1 Year & $11 / 2$ Years & 2 Years \\
\hline Camphene & 0.5 & 2.2 & 1.6 \\
1,8 cineol & 0.5 & 2.2 & 2.2 \\
Camphor & 2.4 & 2.1 & 2.8 \\
Borneol & 8.0 & 5.0 & 6.1 \\
Cinnamaldehyde & 0.4 & 1.6 & 1.9 \\
Ethyl cinnamate & 16.3 & 17.1 & 18.7 \\
Quinazoline-4 & 0.4 & 0.9 & 0.3 \\
phenyl -3-oxide & & & 40.9 \\
Ethy] p-methoxy & 25.8 & 37.8 & \\
cinnamate & & & \\
\hline
\end{tabular}

Evaluation of the performance of $K$. galanga grown under coconut and in open conditions: This study was carried out at Walpita farm in Kotakadeniya Age of the coconut plantation was 46 years and available sunlight was approximately $60 \%$ underneath the coconut which was planted at $8.5 \mathrm{~m} \times 8.5 \mathrm{~m}$ spacing. The soil was moderately deep gravel. The $K$. galanga plants were established in $4 \mathrm{~m} \times 6 \mathrm{~m}$ size plots prepared at the center of the coconut square. Plots were laid in Complete Randomized Block Design with three replications. Initially $500 \mathrm{~kg}$ of super phosphate was added to each plot. This was followed by $10 \mathrm{~kg}$ of dried cattle manure to each plot once in every three months. Another set of $K$. galanga plants were established in an open area (without coconut). The other management practices were similar. Growth and reproductive parameters were recorded monthly and the assessment of chemical quality was undertaken once in six months.

Table 4: Yield performance of $\boldsymbol{K}$. galanga in open area and under coconut

\begin{tabular}{|c|c|c|c|c|c|c|c|c|}
\hline \multirow[t]{2}{*}{$\begin{array}{l}\mathrm{K} . \\
\text { galanga }\end{array}$} & \multicolumn{2}{|c|}{$\begin{array}{c}\text { Yield at one } \\
\text { year (g/plant) }\end{array}$} & \multicolumn{2}{|c|}{$\begin{array}{l}\text { Yield at one } \\
\text { year(kg/ha) }\end{array}$} & \multicolumn{2}{|c|}{$\begin{array}{c}\text { Yield at two } \\
\operatorname{years}(\mathrm{g} / \mathrm{plant})\end{array}$} & \multicolumn{2}{|c|}{$\begin{array}{l}\text { Yield at two } \\
\text { years }(\mathrm{kg} / \mathrm{ha})\end{array}$} \\
\hline & Open & $\begin{array}{l}\text { Under } \\
\text { coconut }\end{array}$ & Open & $\begin{array}{l}\text { *Under } \\
\text { coconut }\end{array}$ & Open & $\begin{array}{l}\text { Under } \\
\text { coconut }\end{array}$ & Open & $\begin{array}{l}\text { "Under } \\
\text { coconut }\end{array}$ \\
\hline $\begin{array}{l}\text { Dried } \\
\text { rhizome }\end{array}$ & $39.2^{\prime \prime}$ & $45.2^{b}$ & $1410^{a}$ & $1083^{l}$ & $62.7^{b}$ & $76.6^{\mathrm{a}}$ & $2253^{\mathrm{a}}$ & $1839^{\mathrm{b}}$ \\
\hline
\end{tabular}

Area outside $2 \mathrm{~m}$ radius of coconut manure circle. The yield is based on total coconut area and not the effective planted area.

Between columns, values sharing a common letter (super script) do not differ significantly at $\mathrm{p}=0.05$ 
Evaluation of the performance of $K$. galanga in different soil types: This too was carried out at Walpita estate and the status of the coconut estate was similar to that described in the previous experiment. Three types of soil namely sandy loam, moderately deep gravel and shallow gravel were selected. Experiment was carried out as mentioned before. Five plants were uprooted from each plot once in six months for the dry weight measurement and chemical analysis.

Table 5: Yield performance of $K$. galanga after one year under coconut in different soils

\begin{tabular}{lcc}
\hline Type of soil & Dry weight $(\mathrm{kg} / \mathrm{ha})$ & Essentital oil content (\%) \\
\hline Sandy loam & $849^{\mathrm{a}}$ & 5.45 \\
Deep gravel & $1317^{\mathrm{b}}$ & 3.35 \\
Shallow gravel & $1438^{\mathrm{b}}$ & 4.36 \\
\hline
\end{tabular}

' The values sharing a common letter (Superscript) do not differ. significantly at, $p=0.05$

Table 6: Variation in volatile oil content of rhizome oil of $K$. galanga with maturity and under different conditions

\begin{tabular}{ccc}
\hline Age of the plant in years & \multicolumn{2}{c}{ Yield of volatile oi] $(\%)$} \\
\cline { 2 - 3 } & Under coconut & Open \\
\hline 1 & 7.85 & 7.19 \\
$11 / 2$ & 3.32 & 3.08 \\
2 & 3.31 & 3.25 \\
\hline
\end{tabular}

Table 7: Antibacterial activity of Kaempheria galanga

\begin{tabular}{llll}
\hline \multirow{2}{*}{ Sample } & \multicolumn{3}{c}{ Inhibition zones in cm } \\
\cline { 2 - 4 } & \multicolumn{1}{c}{ S.aureus } & E.coli & P. aeruginosa \\
\hline Rhizome oil $5 \mathrm{mg}$ & $1.33 \pm 0.057$ & 1.2 & 1.1 \\
Rhizome oil $8 \mathrm{mg}$ & $1.33 \pm 0.04$ & $1.3 \pm 0.01$ & 1.00 \\
Root oil 5mg & $1.36 \pm 0.04$ & 1.2 & 1.00 \\
Root oil 8mg & $1.46 \pm 0.044$ & $1.33 \pm 0.057$ & 1.00 \\
Gentamicin 5mg & $1.43 \pm 0.044$ & 1.3 & $1.33 \pm 0.057$ \\
Gentamicin 8mg & $2.9 \pm 0.13$ & $1.9 \pm 0.17$ & $2.57 \pm 0.115$ \\
Control (pentanehexane) & 1.00 & 1.0 & 1.00 \\
\hline
\end{tabular}


Antibacterial screening: The antibacterial activity was studied by the 'Disk diffusion method' " using Staphylococcus aureus (NCTC 6511), Escherichia coli, (NCTC 10418) and Pseudomonas aeruginosa (NCTC 10882). The experiment was conducted in triplicate. The MIC values were determined using the serial dilution technique.

Table 8: The MIC values for Kaempheria galanga volatile oils

\begin{tabular}{lcc}
\hline \multirow{2}{*}{ Sample } & \multicolumn{2}{c}{ MIC value } \\
\cline { 2 - 3 } & S. aureus & E. coli \\
\hline Rhizome oil & $40.0 \mathrm{mg} / \mathrm{ml}$ & $80.0 \mathrm{mg} / \mathrm{ml}$ \\
Root oil & $1.6 \mathrm{mg} / \mathrm{ml}$ & $8.0 \mathrm{mg} / \mathrm{ml}$ \\
Gentamicin & $1 \mu \mathrm{g} / \mathrm{ml}$ & $8 \mu \mathrm{g} / \mathrm{ml}$ \\
\hline
\end{tabular}

Data analysis: Differences between 'open' and 'under coconut' group were tested for significance using analysis of variance (ANOVA) and chi squared test. Results of antibacterial studies are expressed as \pm SEM

\section{RESULTS}

Camphene, 1,8 cineol, camphor, borneol, cinnamaldehyde, ethyl cinnamate, quinazoline-4-phenyl-3-oxide and ethyl $p$-methoxycinnamate were detected in rhizome and root oils.

\section{DISCUSSION}

The GLC studies of $K$. galanga indicate that the constituents of rhizome oil and root oil are similar and they differ only in their quantities. In the rhizome oil the content of ethyl cinnamate increased with maturity while that of ethyl $p$ methoxycinnamate decreased. In the root oil the concentrations of both compounds increased with maturity. (Tables 2 and 3) Quinazoline - 4-phenyl -3-oxide, previously unreported in $K$. galanga essential oils was found to be present. The volatile oil content of rhizomes was higher than that of roots. The yield of rhizome oil decreased with maturity while that of root increased. (Table 1) Though the dry weights of rhizomes increased with maturity (Table 4) the quality decreased as the essential oil content dropped. (Table 6) Therefore it can be concluded that the best time to harvest the rhizomes is at the age of one year. Higher yields were obtained from plants grown in shallow gravel soil compared to those in deep gravel and sandy loam soils (Table 5).

The root and rhizome oils of $K$. galanga showed marked activity against $S$. aureus and $E$. coli. The root oil showed higher activity than the rhizome oil and 
this was particularly evident from the more sensitive liquid medium inhibition test. The use of $K$. galanga in traditional medicine may be attributed to these properties.

\section{Acknowledgement}

The authors are grateful to the International Foundation for Science, Sweden and the Council for Agricultural Research Policy for financial assistance.

\section{References}

1. The Wealth of Asia (Raw materials) (1959). Council of Scientific \& Industrial Research, New Delhi, vol.v: 314pp.

2. Paniker P.M.B., Rao B.S. \& Simonsen J.L. (1926). Essential oil from the rhizomes of Kaempheria galanga. Journal of Indian Insttute of Science 9A, 133.

3. Noro T., Miyase T., Kuroyanuge M., Ueno A. \& Fukushima S. (1983). Monoamine oxidase inhibitor from the rhizomes of Kaempheria galanga. Chemical Pharmacological Bulletin 31(8): 2708.

4. Jayaweera D.M.A. (1982). Medicinal Plants used in Ceylon. The National Science Council of Sri Lanka, Colombo Vol.v: 209pp.

5. Wong K.C, Ong K.S \& Lim L.L, (1992). Composition of the essential oil of rhizomes of Kaempheria galanga. Flavour and fragrance 7: 263.

6. Kiuchi F., Nakmura N. \& Tsuda Y. (1987). 3-Caren-5-one from Kaempheria galanga. Phytochemistry, 26: 3350 .

7. Bawre A.W. \& Kirby W.M. (1966). Antibiotic susceptibility testing by a standardized single disk method. American. Journal of Clinical Pathology 45: 493

8. Barry A. (1976). The Antimicrobic Susceptibility Test: Principles and. Practices. 236pp. Lea \& Febiger. Philadelphia. 